\title{
PENGARUH PEMBELAJARAN KOOPERATIF JIGSAW DAN MOTIVASI BELAJAR TERHADAP HASIL BELAJAR MEMAHAMI PARAGRAF
}

\author{
Sri Wahyuningsih \\ SMA N 1 Ngoro, Mojokerto \\ marsajawahir@yahoo.com
}

\begin{abstract}
ABSTRAK
Penelitian ini bertujuan untuk (1) mendeskripsikan pengaruh metode pembelajaran Jigsaw terhadap kemampuan memahami paragraf, (2) mendeskripsikan pengaruh motivasi belajar terhadap kemampuan memahami paragraf, dan (3) mendeskripsikan pengaruh metode pembelajaran tipe Jigsaw dan motivasi belajar terhadap kemampuan memahami paragraf. Desain/rancangan dalam penelitian ini menggunakan metode Eksperimen. Populasi dari penelitian ini sejumlah 152 siswa dan sampelnya sejumlah 30 siswa yang pengambilannya dengan menggunakan teknik Classter sampling. Untuk memperoleh data, digunakan instrument tes untuk mendapatkan data hasil belajar dan angket untuk mendapatkan data motivasi belajar. Selanjutnya untuk menganalisis data guna menguji hipotesis digunakan rumus Uji $\mathrm{t}\left(\mathrm{t}_{\text {test }}\right)$. Hasil pengolahan data untuk pengujian hoptesis, dapat dipaparkan bahwa (1) test (4.366) > $t_{\text {tabel }}(2,048)$ dan berdasarkan taraf signifikansi 5\% maka $\mathrm{H}_{\mathrm{o}}$ ditolak dan $\mathrm{H}_{\mathrm{a}}$ diterima, (2) $\mathrm{t}_{\text {test }}(2,088)>\mathrm{t}_{\text {tabel }}(2,048)$ dan berdasarkan taraf signifikansi 5\% maka $\mathrm{H}_{\mathrm{o}}$ ditolak dan $\mathrm{H}_{\mathrm{a}}$ diterima dan (3) (4.665) $>\mathrm{t}_{\text {tabel }}$ $(2,048)$ dan berdasarkan taraf signifikansi $5 \%$ maka $\mathrm{H}_{\mathrm{o}}$ ditolak dan $\mathrm{H}_{\mathrm{a}}$ diterima. Berdasarkan hasil pengolahan data, dapat disimpulkan bahwa ada pengaruh metode pembelajaran Jigsaw terhadap kemampuan memahami paragraf, ada pengaruh motivasi belajar terhadap kemampuan memahami paragraf, dan ada pengaruh metode pembelajaran tipe Jigsaw dengan motivasi belajar terhadap kemampuan memahami paragraf
\end{abstract}

Kata kunci : hasil belajar, motivasi belajar, pembelajaran Jigsaw

ABSTRACT

Research objectives are (1) Describe the learning methods Jigsaw influence on the ability to understand a paragraph; (2) Describe the effect of learning motivation on the ability to understand a paragraph; and (3) Describe the effect of learning methods Jigsaw and motivation to learn the ability to understand a paragraph.Design in this study using Experiment. The population of a number of 152 students and the sample number of 30 students that their extraction using Classter sampling techniques. To obtain the data, the test instrument used to obtain data from study and a questionnaire to obtain data motivation to learn. Furthermore, to analyze the data in order to test the hypothesis of one, two, and three, the formula t test (ttest) is used.The data processing for testing hoptesis, it can be presented that (1) $t_{\text {test }}(4.366)>t_{\text {table }}(2.048)$ and based on the significance level of $5 \%$, then Ho is rejected and $\mathrm{Ha}$ accepted, (2) $\mathrm{t}_{\text {test }}(2.088)>\mathrm{t}_{\text {table }}(2.048)$ and by significance level of 5\%, then Ho is rejected and Ha accepted and (3) (4665) $>t_{\text {table }}(2.048)$ and based on the significance level of $5 \%$, then Ho is rejected and $\mathrm{Ha}$ 
accepted.Based on the results of data processing can be summarized as follows: (1) There is an effect of learning methods Jigsaw on the ability to understand a paragraph, (2) There is an effect of learning motivation on the ability to understand a paragraph, and (3) There is an effect of learning methods Jigsaw and motivation to learning ability to understand a paragraph.

Keywords: learning outcomes, learning jigsaw, motivation to learn

PENDAHULUAN

Upaya pembaharuan dibidang pendidikan pada dasarnya diarahkan pada usaha penguasaan materi, media, dan model pembelajaran yang digunakan. Model pembelajaran diarahkan pada peningkatan aktivitas siswa dalam proses belajar mengajar sehingga proses belajar mengajar berlangsung secara optimal antara guru dan siswa. Dengan kata lain, untuk meningkatkan hasil belajar siswa diperlukan peran kreatif yang membuat pembelajaran Bahasa Indonesia menjadi lebih baik, menarik, dan disukai oleh peserta didik.

Guru mengemban tugas mendampingi peserta didik mencapai tujuan pendidikan secara keseluruhan. Salah satu kompetensi yang harus dikuasai oleh guru adalah menguasai alat pembelajaran yang dituangkan dalam media. Selain media yang relevan. Seorang guru juga harus mampu menggunakan model-model pembelajaran yang sesuai dengan materi ajar. Hal tersebut diupayakan untuk meningkatkan motivasi dan hasil belajar siswa. Masalah tentang kurangnya motivasi dan hasil belajar siswa sering dijumpai apabila guru kurang member variasi model pembelajaran dan media yang menarik dan mampu meningkatkan pemahaman terhadap materi.

Materi pokok paragraf pada mata pelajaran Bahasa Indonesia menuntut pemahaman siswa terhadap rangkaian kalimat yang terdapat di dalamnya. Salah satu model pembelajaran yang dapat diterapkanan dalam pembelajaran adalah pembelajaran kooperatif tipe Jigsaw. Pembelajaran kooperatif merupakan pembelajaran yang memberi kesempatan kepada siswa untuk bekerja sama dengan sesama siswa dalam tugas-tugas terstruktur. Pembelajaran kooperatif juga dikenal dengan pembelajaran secara berkelompok, belajar kelompok, kerja kelompok. Sehingga memungkinkan terjadinya interaksi secara terbuka hubungannya bersifat interdependensi efektif di antara anggota kelompok (Chotimah dan Dwitasari, 2009: 1-2).

Pembelajaran kooperatif tipe Jigsaw adalah suatu metode yang ingin menumbuhkan rasa percaya diri yang kuat dalam diri siswa agar mampu menjadi sumber belajar bagi teman-temannya (Chotimah, 2004:70). Pembelajaran tipe Jigsaw dapat menimbulkan rasa percaya diri kepada siswa dari rasa minder atau malu tampil di depan. Hal tersebut perlu dilakukan berkali-kali supaya terlatih.

Dengan hal tersebut, diharapkan pemahaman pada subpokok bahasan paragraf dapat dikuasai dengan baik oleh peserta didik dengan adanya tim ahli. Alasan penggunaan model pembelajaran kooperatif Jigsaw adalah agar terdapat pembagian kerja yang baik di antara peserta didik yang disertai dengan ketergantungan positif satu sama lain untuk menguasai seluruh materi paragraf. 
Metode yang digunakan adalah quasi experimental desain. Hal tersebut dimaksudkan untuk mengumpulkan informasi atau data tentang akibat adanya suatu treatmen atau perlakuan dengan menggunakan penelitian "pasca tes". Penelitian ini berupaya untuk mengungkapkan hubungan sebab akibat dengan cara melibatkan satu kelas yang diberi perlakuan, yaitu menggunakan kooperatif Jigsaw.

Dalam penetapan sampling, peneliti memungkinkan memilih dan memilah subjek penelitian yang sesuai dengan rancangan penelitian. Kelompok tersebut dipilih dengan teknik cluster atau dipilih dengan prosentase dari jumlah populasi. Karena jumlah populasi lebih dari 100, peneliti mengambil sampel antara $20-25 \%$ dari populasi yang terdiri atas 5 kelas yang berjumlah 152 siswa, yakni 30 siswa. Dengan sampel sejumlah itu diharapkan sudah memenuhi persyaratan pengambilan sampel. Menurut Arikunto (2010:185), classter sampling adalah pengambilan sampel dengan mempertimbangkan kelompok-kelompok atau perwakilan yang ada.

Analisis data merupakan pengolahan data yang dikumpulkan peneliti dan selanjutnya digunakan untuk pengambilan kesimpulan dari data yang diperoleh sebagai perwujudan hipotesis.

(1) Hipotesis pertama terdiri dari 2 variabel, yaitu model pembelajaran jigsaw $\left(\mathrm{X}_{1}\right)$ yang menghasilkan data nominal dan hasil belajar/ kemampuan memahami paragrap (Y) yang menghasilkan data interval. Untuk membuktikan hipotesis pertama digunakan rumus Uji t ( $\left.t_{\text {test. }}\right)$ (IB Netra 1984:91), sebagai berikut.

$$
t_{\text {test }}=\frac{\mathrm{M}_{\mathrm{I}}-\mathrm{M}_{\mathrm{II}}}{S E_{M D}}
$$

Keterangan:

M ${ }_{\mathrm{I}} \quad$ Rata-rata nilai kemampuan memahami paragraf setelah mengikuti proses pembelajaran yang menerapkan metode Jigsaw

$\mathrm{M}_{\mathrm{II}}$ = Rata-rata nilai kemampuan memahami paragraf sebelum mengikuti proses pembelajaran yang menerapkan metode Jigsaw

SEMD $=$ Kesalahan estándar perbedaan angka rata-rata

(2) Hipotesis kedua terdiri dari 2 variabel, yaitu motivasi belajar $\left(\mathrm{X}_{2}\right)$ yang menghasilkan data interval dan hasil belajar/kemampuan memahami paragraf (Y) yang menghasilkan data interval. Untuk membuktikan hipotesis kedua, menurut IB Netra(1984: 91), dapat menggunakan rumus Uji t $\left(t_{\text {test. }}\right)$ sebagai berikut.

$$
t_{\text {test }}=\frac{M_{\mathrm{I}}-\mathrm{M}_{\mathrm{II}}}{S E_{M D}}
$$

Keterangan:

$\mathrm{M}_{\mathrm{I}}$ = Rata-rata nilai kemampuan memahami paragraf setelah mengikuti proses pembelajaran yang menerapkan metode Jigsaw

MII = Rata-rata nilai kemampuan memahami paragraf sebelum mengikuti proses pembelajaran yang menerapkan metode Jigsaw 
SEMD $=$ kesalahan estándar perbedaan angka rata-rata

(3) Hipotesis ketiga yang terdiri dari 3 variabel, yaitu model pembelajaran jigsaw $\left(\mathrm{X}_{1}\right)$ yang menghasilkan data nominal, motivasi belajar $\left(\mathrm{X}_{2}\right)$ yang menghasilkan data interval, dan variabel hasil belajar/kemampuan memahami paragraph (Y) yang menghasilkan data interval. Kemudian untuk membuktikan hipotesis ketiga, menurut Riduwan (2004:171) dapat menggunakan rumus $\boldsymbol{U j i \boldsymbol { t }}$ ( $\left(_{\text {test }}\right.$. sebagai berikut.

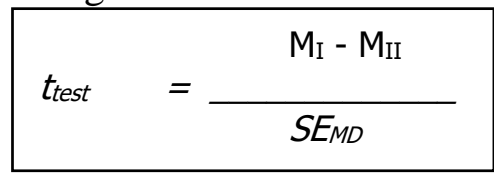

Keterangan:

$\mathrm{M}_{\mathrm{I}} \quad$ = Rata-rata nilai kemampuan memahami paragraf setelah mengikuti proses pembelajaran yang menerapkan metode Jigsaw

$\mathrm{M}_{\mathrm{II}} \quad=$ Rata-rata nilai kemampuan memahami paragraf sebelum mengikuti proses pembelajaran yang menerapkan metode Jigsaw

$\mathrm{SE}_{\mathrm{MD}}=$ kesalahan estándar perbedaan angka rata-rata

\section{PEMBAHASAN Data tentang Hasil Belajar/ Kemampuan memahami Paragraf}

Hasil pretest dan postest serta perkembangan tentang kemampuan memahami paragraf adalah sebagai berikut.

Tabel 3.1 Daftar Nilai Hasil Pretest Kemampuan Memahami Paragraf

\begin{tabular}{|c|l|c|c|c|c|}
\hline \multirow{2}{*}{ No } & \multicolumn{2}{|c|}{ Nama Siswa } & \multicolumn{2}{|c|}{ Nilai } & \multirow{2}{*}{$\%$} \\
\cline { 3 - 4 } & & Pretest & Postest & & \\
\hline 1 & Ana Komariya & 70 & 80 & 10 & 14.29 \\
\hline 2 & Angger Lukita Sari & 80 & 90 & 10 & 12.50 \\
\hline 3 & Cici Dwi Krisma Wardani & 80 & 80 & 0 & 0.00 \\
\hline 4 & Defi Oktavia Puji Astutik & 60 & 80 & 20 & 33.33 \\
\hline 5 & Dwi Ratnasari & 80 & 90 & 10 & 12.50 \\
\hline 6 & Elfia Suci Rahayu & 70 & 80 & 10 & 14.29 \\
\hline 7 & Ilil Rahmawati & 50 & 70 & 20 & 40.00 \\
\hline 8 & Istiqlalia Mashlaha & 60 & 70 & 10 & 16.67 \\
\hline 9 & Lailatul Aldawiyah & 60 & 70 & 10 & 16.67 \\
\hline 10 & Lailil Mukarromah & 80 & 80 & 0 & 0.00 \\
\hline 11 & Leo Duwi Susanto & 80 & 90 & 10 & 12.50 \\
\hline 12 & Luchman Hakim & 50 & 60 & 10 & 20.00 \\
\hline 13 & Lukluil Ma'nun & 90 & 90 & 0 & 0.00 \\
\hline 14 & Lukman Hadi Wibowo & 50 & 50 & 0 & 0.00 \\
\hline 15 & Maulida Ulfa & 50 & 60 & 10 & 20.00 \\
\hline 16 & Mohammad Jaeni & 40 & 50 & 10 & 25.00 \\
\hline 17 & Muhammad Ariep Budiman & 50 & 50 & 0 & 0.00 \\
\hline 18 & Muhammad Herlis Atmayuda & 40 & 50 & 10 & 25.00 \\
\hline 19 & Nofi Audina & 50 & 60 & 10 & 20.00 \\
\hline 20 & Novia Rizki Hidayanti & 50 & 60 & 10 & 20.00 \\
\hline 21 & Noviatus Sa'ida & 70 & 80 & 10 & 14.29 \\
\hline 22 & Novita Intan Fadilah & 60 & 70 & 10 & 16.67 \\
\hline 23 & Savira Adelia Sukarto & 60 & 70 & 10 & 16.67 \\
\hline 24 & Silvia Nur Aini & 70 & 90 & 20 & 28.57 \\
\hline 25 & Siti Nur Machfiro & 40 & 90 & 20 & 28.57 \\
\hline 26 & Siti Rohmatus Syaidah & 50 & 60 & 10 & 20.00 \\
\hline 27 & Vicko Fergiansyah Novari R & & & & \\
\hline & & 70 & 30 & 75.00 \\
\hline
\end{tabular}


Pengaruh Pembelajaran Kooperatif Jigsaw dan Motivasi Belajar Terhadap Hasil Belajar Memahami Paragraf

\begin{tabular}{|c|c|c|c|c|c|}
\hline \multirow{2}{*}{ No } & \multirow{2}{*}{ Nama Siswa } & \multicolumn{2}{|c|}{ Nilai } & \multirow{2}{*}{$+/-$} & \multirow{2}{*}{$\%$} \\
\cline { 3 - 4 } & & Pretest & Postest & & \\
\hline 28 & Yuhana Putri Setiawan & 50 & 50 & 0 & 0.00 \\
\hline 29 & Yulan Albit Al Wahyu & 70 & 80 & 10 & 14.29 \\
\hline 30 & Yusni Irmawan & 40 & 50 & 10 & 25.00 \\
\hline \multicolumn{2}{|c|}{ Jumlah } & $\mathbf{1 8 2 0}$ & $\mathbf{2 1 2 0}$ & $\mathbf{3 0 0}$ & $\mathbf{5 4 2}$ \\
\hline Rata-rata & $\mathbf{6 0 . 6 7}$ & $\mathbf{7 0 . 6 7}$ & $\mathbf{1 0 . 0 0}$ & $\mathbf{1 8 . 0 6}$ \\
\hline
\end{tabular}

Berdasarkan tabel 3.1, dapat dipaparkan bahwa tingkat hasil belajar/kemampuan memahami paragraf, yaitu (1) nilai rata-rata pretest sebesar 60,67 sedangkan nilai rata-rata postest sebesar 70,67 berarti terjadi ada kenaikan sebesar 10 point atau naik $18.06 \%$, (2) nilai tertinggi pretest sebesar 90 sedangkan posttest sebesar 90 berarti tidak terjadi kenaikan, dan (3) nilai terendah pretest sebesar 40 sedangkan posttest sebesar 50 berarti ada kenaikan sebesar 10 point atau naik $25 \%$.

Tabel 2 Distribusi Frekuensi Nilai Pretest dalam Proses Pembelajaran yang Menerapkan Model Pembelajaran Jigsaw

\begin{tabular}{|c|c|c|c|}
\hline Interval Kelas & Frekuensi & Kriteria & Prosentase (\%) \\
\hline $91-100$ & 0 & Amat baik & 0.00 \\
\hline $75-90$ & 6 & Baik & 20.00 \\
\hline $60-74$ & 11 & Cukup & 36.67 \\
\hline $40-59$ & 13 & Kurang & 43.33 \\
\hline$<40$ & 0 & Kurang sekali & 0.00 \\
\hline Jumlah & $\mathbf{3 0}$ & & $\mathbf{1 0 0 . 0 0}$ \\
\hline
\end{tabular}

Tabel 3 Distribusi Frekuensi Nilai Postest dalam Proses Pembelajaran yang Menerapkan Model Pembelajaran Jigsaw

\begin{tabular}{|c|c|c|c|}
\hline Interval Kelas & Frekuensi & Kriteria & Prosentase $(\%)$ \\
\hline $91-100$ & 0 & Amat baik & 0.00 \\
\hline $75-90$ & 14 & Baik & 46.67 \\
\hline $60-74$ & 10 & Cukup & 33.33 \\
\hline $40-59$ & 6 & Kurang & 20.00 \\
\hline$<40$ & 0 & Kurang sekali & 0.00 \\
\hline Jumlah & $\mathbf{3 0}$ & & $\mathbf{1 0 0 . 0 0}$ \\
\hline
\end{tabular}

Berdasarkan tabel 2 dan 3, dapat dipaparkan data hasil penelitian tingkat hasil belajar/kemampuan memahami paragraf, yaitu pada saat pretest sebanyak 6 responden atau $20 \%$ yang mencapai tingkat hasil belajar baik (75-90), sedangkan postest sebanyak 14 responden atau $46,67 \%$ yang mencapai tingkat hasil belajar baik (75-90). Hal tersebut menunjukkan adanya kenaikan sebanyak 8 responden atau naik $26,67 \%$

\section{Data tentang Motivasi Belajar}

Tabel 4 Hasil Skor Angket Motivasi Belajar Sebelum dan Sesudah Pelaksanaan Metode Jigsaw dalam Proses Pembelajaran

\begin{tabular}{|l|l|c|c|c|c|}
\hline \multirow{2}{*}{ No } & \multirow{2}{*}{ Nama Siswa } & \multicolumn{2}{|c|}{ Skor angket } & \multirow{2}{*}{ +/- } & \multirow{2}{*}{$\%$} \\
\cline { 3 - 4 } & & Sebelum & Sesudah & & \\
\hline 1 & Ana Komariya & 66 & 69 & 3 & 4.55 \\
\hline 2 & Angger Lukita Sari & 70 & 71 & 1 & 1.43 \\
\hline 3 & Cici Dwi Krisma Wardani & 71 & 71 & 0 & 0.00 \\
\hline 4 & Defi Oktavia Puji Astutik & 66 & 67 & 1 & 1.52 \\
\hline
\end{tabular}




\begin{tabular}{|c|c|c|c|c|c|}
\hline \multirow{2}{*}{ No } & \multirow{2}{*}{ Nama Siswa } & \multicolumn{2}{|c|}{ Skor angket } & \multirow{2}{*}{$+/-$} & \multirow{2}{*}{$\%$} \\
\hline & & Sebelum & Sesudah & & \\
\hline 5 & Dwi Ratnasari & 73 & 76 & 3 & 4.11 \\
\hline 6 & Elfia Suci Rahayu & 66 & 69 & 3 & 4.55 \\
\hline 7 & Ilil Rahmawati & 37 & 51 & 14 & 37.84 \\
\hline 8 & Istiqlalia Mashlaha & 73 & 73 & 0 & 0.00 \\
\hline 9 & Lailatul Aldawiyah & 72 & 72 & 0 & 0.00 \\
\hline 10 & Lailil Mukarromah & 66 & 70 & 4 & 6.06 \\
\hline 11 & Leo Duwi Susanto & 66 & 71 & 5 & 7.58 \\
\hline 12 & Luchman Hakim & 72 & 72 & 0 & 0.00 \\
\hline 13 & Lukluil Ma'nun & 67 & 70 & 3 & 4.48 \\
\hline 14 & Lukman Hadi Wibowo & 37 & 39 & 2 & 5.41 \\
\hline 15 & Maulida Ulfa & 39 & 47 & 8 & 20.51 \\
\hline 16 & Mohammad Jaeni & 37 & 41 & 4 & 10.81 \\
\hline 17 & Muhammad Ariep Budiman & 39 & 41 & 2 & 5.13 \\
\hline 18 & Muhammad Herlis Atmayuda & 37 & 42 & 5 & 13.51 \\
\hline 19 & Nofi Audina & 39 & 51 & 12 & 30.77 \\
\hline 20 & Novia Rizki Hidayanti & 39 & 44 & 5 & 12.82 \\
\hline 21 & Noviatus Sa'ida & 71 & 72 & 1 & 1.41 \\
\hline 22 & Novita Intan Fadilah & 69 & 71 & 2 & 2.90 \\
\hline 23 & Savira Adelia Sukarto & 69 & 69 & 0 & 0.00 \\
\hline 24 & Silvia Nur Aini & 72 & 73 & 1 & 1.39 \\
\hline 25 & Siti Nur Machfiro & 66 & 70 & 4 & 6.06 \\
\hline 26 & Siti Rohmatus Syaidah & 37 & 51 & 14 & 37.84 \\
\hline 27 & Vicko Fergiansyah Novari R & 39 & 42 & 3 & 7.69 \\
\hline 28 & Yuhana Putri Setiawan & 37 & 37 & 0 & 0.00 \\
\hline 29 & Yulan Albit Al Wahyu & 69 & 70 & 1 & 1.45 \\
\hline 30 & Yusni Irmawan & 37 & 40 & 3 & 8.11 \\
\hline & Jumlah & 1598 & 1802 & 104 & 238 \\
\hline & Rata-rata & 55.30 & 60.07 & 4.77 & 8.63 \\
\hline
\end{tabular}

Berdasarkan tabel 4, dapat dipaparkan data hasil penelitian skor motivasi belajar siswa, yaitu (1) skor rata-rata sebelum sebesar 55.30 sedangkan skor rata-rata postest sebesar 60,07 berarti terjadi ada kenaikan sebesar 4,77 point atau naik 8,63\%, (2) skor tertinggi sebelum sebesar 90 sedangkan posttest sebesar 90 berarti tidak terjadi kenaikan, dan (3) skor terendah sebelum sebesar 37 sedangkan sesudah sebesar 40 berarti ada kenaikan sebesar 3 point atau naik $7.93 \%$.

Tabel 5 Hasil Angket tentang Motivasi Belajar Siswa Sebelum Pelaksanaan Proses Pembelajaran yang Menerapkan Metode Jigsaw

\begin{tabular}{|c|l|c|c|}
\hline Interval & Kriteria & Frekuensi & $\%$ \\
\hline $41-80$ & Tinggi & 18 & 60 \\
\hline $20-40$ & Rendah & 12 & 40 \\
\hline \multicolumn{2}{|c|}{ Jumlah } & 30 & 100 \\
\hline
\end{tabular}

Tabel 6 Hasil Angket tentang Motivasi Belajar Siswa Setelah Pelaksanaan Proses Pembelajaran yang Menerapkan Metode Jigsaw

\begin{tabular}{|c|c|c|c|}
\hline Interval & Kriteria & Frekuensi & $\%$ \\
\hline $41-80$ & Tinggi & 27 & 90 \\
\hline $20-40$ & Rendah & 3 & 10 \\
\hline \multicolumn{2}{|c|}{ Jumlah } & 30 & 100 \\
\hline
\end{tabular}

Berdasarkan tabel 5 dan tabel 6, dapat dipaparkan data hasil penelitian tingkat motivasi belajar siswa, yaitu pada saat sebelum 
pelaksanaan metode jigsaw sebanyak 18 responden atau $60 \%$ yang mencapai tingkat motivasi belajar tinggi $(41-80)$, sedangkan setelah pelaksanaan metode jigsaw sebanyak 27 responden atau $90 \%$ yang mencapai tingkat motivasi belajar tinggi (41-80). Hal tersebut menunjukkan bahwa terdapat kenaikan sebanyak 9 responden atau naik $30 \%$

\section{Pengujian Hipotesis}

1. Pengujian Hipotesis Pertama

Berpijak pada hasil analisis Pengujian Hipotesis Pertama tentang "Ada pengaruh metode pembelajaran Jigsaw terhadap kemampuan memahami paragraph" dengan membandingkan nilai rata-rata postest dengan nilai rata-rata pretest yaitu 70.67> 60,67. Kemudian, dilakukan pengujian dengan menggunakan rumus Uji $\mathrm{t}$ (test), sebagai berikut.

Tabel 7 Hasil Perhitungan Pengaruh Model Pembelajaran Jigsaw terhadap Hasil Belajar Siswa dengan Menggunkan Rumus Uji t

\begin{tabular}{|c|c|c|c|}
\hline $\begin{array}{c}\mathrm{X}_{1} \\
\text { (Sebelum perlakuan) }\end{array}$ & $\mathrm{X}_{1}^{2}$ & $\begin{array}{c}\mathrm{X}_{2} \\
\text { (Sesudah perlakuan) }\end{array}$ & $\mathrm{X}_{2}{ }^{2}$ \\
\hline 70 & 4900 & 80 & 6400 \\
\hline 80 & 6400 & 90 & 8100 \\
\hline 80 & 6400 & 80 & 6400 \\
\hline 60 & 3600 & 80 & 6400 \\
\hline 80 & 6400 & 90 & 8100 \\
\hline 70 & 4900 & 80 & 6400 \\
\hline 50 & 2500 & 70 & 4900 \\
\hline 60 & 3600 & 70 & 4900 \\
\hline 60 & 3600 & 70 & 4900 \\
\hline 80 & 6400 & 80 & 6400 \\
\hline 80 & 6400 & 90 & 8100 \\
\hline 50 & 2500 & 60 & 3600 \\
\hline 90 & 8100 & 90 & 8100 \\
\hline 50 & 2500 & 50 & 2500 \\
\hline 50 & 2500 & 60 & 3600 \\
\hline 40 & 1600 & 50 & 2500 \\
\hline 50 & 2500 & 50 & 2500 \\
\hline 40 & 1600 & 50 & 2500 \\
\hline 50 & 2500 & 60 & 3600 \\
\hline 50 & 2500 & 60 & 3600 \\
\hline 70 & 4900 & 80 & 6400 \\
\hline 60 & 3600 & 70 & 4900 \\
\hline 60 & 3600 & 70 & 4900 \\
\hline 70 & 4900 & 90 & 8100 \\
\hline 70 & 4900 & 90 & 8100 \\
\hline 40 & 1600 & 70 & 4900 \\
\hline 50 & 2500 & 60 & 3600 \\
\hline 50 & 2500 & 50 & 2500 \\
\hline 70 & 4900 & 80 & 6400 \\
\hline 40 & 1600 & 50 & 2500 \\
\hline 1820 & 116400 & 2120 & 155800 \\
\hline 60.67 & & 70.67 & \\
\hline
\end{tabular}




$$
\begin{aligned}
& \mathrm{M}_{1}=60.67 \\
& \mathrm{M}_{2}=70.67 \\
& \mathrm{SD}_{1}=\sqrt{\frac{\sum \mathrm{fx}^{2}}{N}}-\left(\frac{\sum \mathrm{fX}}{N}\right)^{2} \\
& \mathrm{SD}_{1}=\sqrt{\frac{116400}{30}}-\left(\frac{1820}{30}\right)^{2} \\
& \mathrm{SD}_{1}=14.13 \\
& \mathrm{SE}^{2} \mathrm{M} 1=\frac{S D 1}{\sqrt{N-1}} \\
& \mathrm{SE}^{2} \mathrm{M} 1=\frac{14.13}{\sqrt{29}} \\
& \mathrm{SE}^{2} \mathrm{M} 1=2.62 \\
& \mathrm{SD}_{2}=\sqrt{\frac{\sum \mathrm{fx}^{2}}{N}}-\left(\frac{\sum \mathrm{fX}}{N}\right)^{2} \\
& \mathrm{SD}_{2}=\sqrt{\frac{155800}{30}}-\left(\frac{2120}{30}\right)^{2} \\
& \mathrm{SD}_{1}=14.13 \\
& \mathrm{SE}^{2} \mathrm{M} 2=\frac{S D 1}{\sqrt{N-1}} \\
& \mathrm{SE}^{2} \mathrm{M} 2=\frac{14.13}{\sqrt{29}} \\
& \mathrm{SE}^{2} \mathrm{M} 2=2.62 \\
& \mathrm{SE}_{\mathrm{MD}}=\sqrt{\mathrm{SE} 2} \mathrm{M} 2+\mathrm{SE} 2 \mathrm{M} 1 \\
& \mathrm{SE}_{\mathrm{MD}}=\sqrt{2.62}+2.62 \\
& \mathrm{SEMD}_{\mathrm{M}}=2.62 \\
& \mathrm{t}=\frac{M 2-M 1}{\mathrm{SEMD}} \\
& \mathrm{t} \quad=\frac{70,67-60,67}{2.62} \\
& \mathrm{t} \quad=4.366 \\
& \text { df } \quad=\mathrm{N}-2=30-2=28 \\
& \text { taraf signifikansi 5\% } \\
& t_{\text {tabel }}=2,048 \\
& \text { Jadi test }(4.366)>t_{\text {tabel }}(2,048)
\end{aligned}
$$

Berdasarkan taraf Signifikansi 5\%, Ho yang berbunyi, "Tidak ada pengaruh metode pembelajaran Jigsaw terhadap kemampuan memahami paragraf" ditolak dan $\mathrm{H}_{\mathrm{a}}$ yang berbunyi, "Ada pengaruh metode pembelajaran Jigsaw terhadap kemampuan memahami paragraf" diterima.

\section{Pengujian Hipotesis Kedua}

Berpijak pada hasil analisis Pengujian Hipotesis kedua tentang "Ada pengaruh motivasi belajar terhadap kemampuan memahami paragraf" dengan membandingkan skor rata-rata motivasi belajar sebelum proses pembelajaran berlangsung dengan skor rata-rata motivasi belajar setelah proses pembelajaran berlangsung yaitu $60.07>$ 55.30, dilakukan pengujian dengan menggunakan rumus Uji t ( $\left.\mathrm{t}_{\text {est }}\right)$, sebagai berikut. 
Pengaruh Pembelajaran Kooperatif Jigsaw dan Motivasi Belajar Terhadap Hasil Belajar Memahami Paragraf

Tabel 8 Hasil Perhitungan Pengaruh Motivasi Belajar terhadap Kemampuan Memahami Paragraf dengan Menggunakan Rumus Uji t

\begin{tabular}{|c|c|c|c|}
\hline $\begin{array}{c}\mathrm{X}_{1} \\
\text { (Sebelum perlakuan) }\end{array}$ & $\mathrm{X}_{1}^{2}$ & $\begin{array}{c}\mathrm{X}_{2} \\
\text { (Sesudah perlakuan) }\end{array}$ & $\mathrm{X}_{2}^{2}$ \\
\hline 66 & 4356 & 69 & 4761 \\
\hline 70 & 4900 & 71 & 5041 \\
\hline 71 & 5041 & 71 & 5041 \\
\hline 66 & 4356 & 67 & 4489 \\
\hline 73 & 5329 & 76 & 5776 \\
\hline 66 & 4356 & 69 & 4761 \\
\hline 37 & 1369 & 51 & 2601 \\
\hline 73 & 5329 & 73 & 5329 \\
\hline 72 & 5184 & 72 & 5184 \\
\hline 66 & 4356 & 70 & 4900 \\
\hline 66 & 4356 & 71 & 5041 \\
\hline 72 & 5184 & 72 & 5184 \\
\hline 67 & 4489 & 70 & 4900 \\
\hline 37 & 1369 & 39 & 1521 \\
\hline 39 & 1521 & 47 & 2209 \\
\hline 37 & 1369 & 41 & 1681 \\
\hline 39 & 1521 & 41 & 1681 \\
\hline 37 & 1369 & 42 & 1764 \\
\hline 39 & 1521 & 51 & 2601 \\
\hline 39 & 1521 & 44 & 1936 \\
\hline 71 & 5041 & 72 & 5184 \\
\hline 69 & 4761 & 71 & 5041 \\
\hline 69 & 4761 & 69 & 4761 \\
\hline 72 & 5184 & 73 & 5329 \\
\hline 66 & 4356 & 70 & 4900 \\
\hline 37 & 1369 & 51 & 2601 \\
\hline 39 & 1521 & 42 & 1764 \\
\hline 37 & 1369 & 37 & 1369 \\
\hline 69 & 4761 & 70 & 4900 \\
\hline 37 & 1369 & 40 & 1600 \\
\hline 1598 & 103288 & 1802 & 113850 \\
\hline 55.30 & & 60.07 & \\
\hline
\end{tabular}

$\mathrm{M}_{1}=55.30$

$\mathrm{M}_{2}=60.07$

$\mathrm{SD}_{1}=\sqrt{\frac{\sum \mathrm{fx}^{2}}{N}}-\left(\frac{\sum \mathrm{fX}}{N}\right)^{2}$

$\mathrm{SD}_{1}=\sqrt{\frac{103288}{30}}-\left(\frac{1598}{30}\right)^{2}$

$\mathrm{SD}^{2}{ }_{1}=15,47$

$\mathrm{SE}^{2} \mathrm{M} 1=\frac{S D 1}{\sqrt{N-1}}$

$\mathrm{SE}^{2} \mathrm{M} 1=\frac{15,47}{5.385}$

$\mathrm{SE}^{2} \mathrm{M}_{1}=2,67$

$\mathrm{SD}_{2}=\sqrt{\frac{\sum \mathrm{fx}^{2}}{N}}-\left(\frac{\sum \mathrm{fX}}{N}\right)^{2}$ 


$$
\begin{aligned}
& \mathrm{SD}_{2}=\sqrt{\frac{113850}{30}}-\left(\frac{1802}{30}\right)^{2} \\
& \mathrm{SD}_{2}=\sqrt{3795}+3608 \\
& \mathrm{SD}^{2}{ }_{2}=13,67 \\
& \mathrm{SE}^{2} \mathrm{M} 2=\frac{\mathrm{SD} 1}{\sqrt{N-1}} \\
& \mathrm{SE}^{2} \mathrm{M}_{2}=\frac{13,67}{5.385} \\
& \mathrm{SE}^{2} \mathrm{M} 2=2.54 \\
& \mathrm{SEMD}=\sqrt{\mathrm{SE} 2 \mathrm{M} 2}+\mathrm{SE} 2 \mathrm{M} 1 \\
& \mathrm{SEMD}_{\mathrm{M}}=\sqrt{2,54}+2,67 \\
& \mathrm{SEMD}_{\mathrm{MD}}=2,28 \\
& \mathrm{t} \quad=\frac{M 2-M 1}{\mathrm{SEMD}} \\
& \mathrm{t} \quad=\frac{60.07-55,30}{2,28} \\
& \mathrm{t} \quad=2,088 \\
& \mathrm{df} \quad=\mathrm{N}-2=30-2=28 \\
& \text { taraf signifikansi } 5 \% \\
& \mathrm{t} \text { tabel } \quad=2,048 \\
& \text { Jadi ttest }(2,088)>\mathrm{t} \text { tabel }(2,048)
\end{aligned}
$$

Berdasarkan taraf Signifikansi 5\%, Ho yang berbunyi, "Tidak ada pengaruh motivasi belajar terhadap kemampuan memahami paragraf" ditolak dan $\mathrm{H}_{\mathrm{a}}$ yang berbunyi "Ada pengaruh motivasi belajar terhadap kemampuan memahami paragraf" diterima.

\section{Pengujian Hipotesis Ketiga}

Berpijak pada hasil analisis pengujian hipotesis ketiga tentang "pengaruh metode pembelajaran tipe Jigsaw dan motivasi belajar terhadap kemampuan memahami paragraf" dengan membandingkan nilai rata-rata postest dengan skor rata-rata motivasi belajar setelah proses pembelajaran berlangsung yaitu $70.67>60.07$ dilakukan pengujian dengan menggunakan rumus Uji t (ttest) sebagai berikut.

Tabel 9 Hasil Perhitungan Pengaruh Model Pembelajaran Jigsaw dan Motivasi Belajar terhadap Hasil Belajar Siswa dengan Menggunakan

Rumus Uji t

\begin{tabular}{|c|c|c|c|}
\hline $\begin{array}{c}\mathbf{X}_{\mathbf{1}} \\
\text { (hasil belajar) }\end{array}$ & $\mathbf{X}^{\mathbf{2}}$ & $\begin{array}{c}\mathbf{X}_{\mathbf{2}} \\
\text { (motivasi belajar) }\end{array}$ & $\mathbf{X}_{\mathbf{2}}^{\mathbf{2}}$ \\
\hline 80 & 6400 & 69 & 4761 \\
\hline 90 & 8100 & 71 & 5041 \\
\hline 80 & 6400 & 71 & 5041 \\
\hline 80 & 6400 & 67 & 4489 \\
\hline 90 & 8100 & 76 & 5776 \\
\hline 80 & 6400 & 69 & 4761 \\
\hline 70 & 4900 & 51 & 2601 \\
\hline 70 & 4900 & 73 & 5329 \\
\hline 70 & 4900 & 72 & 5184 \\
\hline 80 & 6400 & 70 & 4900 \\
\hline 90 & 8100 & 71 & 5041 \\
\hline 60 & 3600 & 72 & 5184 \\
\hline 90 & 8100 & 70 & 4900 \\
\hline
\end{tabular}


Pengaruh Pembelajaran Kooperatif Jigsaw dan Motivasi Belajar Terhadap Hasil Belajar Memahami Paragraf

\begin{tabular}{|c|c|c|c|}
\hline $\begin{array}{c}\mathbf{X}_{\mathbf{1}} \\
\text { (hasil belajar) }\end{array}$ & $\mathbf{X}^{\mathbf{2}}$ & $\begin{array}{c}\mathbf{X}_{\mathbf{2}} \\
\text { (motivasi belajar) }\end{array}$ & $\mathbf{X}_{\mathbf{2}}{ }^{\mathbf{2}}$ \\
\hline 50 & 2500 & 39 & 1521 \\
\hline 60 & 3600 & 47 & 2209 \\
\hline 50 & 2500 & 41 & 1681 \\
\hline 50 & 2500 & 41 & 1681 \\
\hline 50 & 2500 & 42 & 1764 \\
\hline 60 & 3600 & 51 & 2601 \\
\hline 60 & 3600 & 44 & 1936 \\
\hline 80 & 6400 & 72 & 5184 \\
\hline 70 & 4900 & 71 & 5041 \\
\hline 70 & 4900 & 69 & 4761 \\
\hline 90 & 8100 & 73 & 5329 \\
\hline 90 & 8100 & 70 & 4900 \\
\hline 70 & 4900 & 51 & 2601 \\
\hline 60 & 3600 & 42 & 1764 \\
\hline 50 & 2500 & 37 & 1369 \\
\hline 80 & 6400 & 70 & 4900 \\
\hline 50 & 2500 & 40 & 1600 \\
\hline 2120 & 155800 & 1802 & 113850 \\
\hline 70.67 & & 60.07 & \\
\hline
\end{tabular}

$$
\begin{aligned}
& \mathrm{M}_{1}=70.67 \\
& \mathrm{M}_{2}=60.07 \\
& \mathrm{SD}_{1}=\sqrt{\frac{\sum \mathrm{fx}^{2}}{N}}-\left(\frac{\sum \mathrm{fX}}{N}\right)^{2} \\
& \mathrm{SD}_{1}=\sqrt{\frac{155800}{30}}-\left(\frac{2120}{30}\right)^{2} \\
& \mathrm{SD}^{2}{ }_{1}=14.17 \\
& \mathrm{SE}^{2} \mathrm{M} 1=\frac{S D 1}{\sqrt{N-1}} \\
& \mathrm{SE}^{2} \mathrm{M} 1=\frac{14,17}{5.385} \\
& \mathrm{SE}^{2} \mathrm{M} 1=2,62 \\
& \mathrm{SD}_{2}=\sqrt{\frac{\sum \mathrm{fx}^{2}}{N}}-\left(\frac{\sum \mathrm{fx}}{N}\right)^{2} \\
& \mathrm{SD}_{2}=\sqrt{\frac{113850}{30}}-\left(\frac{1802}{30}\right)^{2} \\
& \mathrm{SD}^{2}{ }_{2}=13,67 \\
& \mathrm{SE}^{2} \mathrm{M} 2=\frac{S D 1}{\sqrt{N-1}} \\
& \mathrm{SE}^{2} \mathrm{M} 2=\frac{13,67}{5.385} \\
& \mathrm{SE}^{2}{ }_{\mathrm{M} 2}=2.54 \\
& \mathrm{SEMD}_{\mathrm{M}}=\sqrt{\mathrm{SE} 2} \mathrm{M} 2+\mathrm{SE} 2 \mathrm{M} 1 \\
& \mathrm{SE}_{\mathrm{MD}}=\sqrt{2,62}+2,54 \\
& \mathrm{SEMD}_{\mathrm{MD}}=2,27 \\
& \mathrm{t}=\frac{M 2-M 1}{\text { SEMD }} \\
& \mathrm{t}=\frac{70,67-60,07}{2,28} \\
& \mathrm{t} \quad=4.665 \\
& \text { Taraf Signifikansi }=5 \% \\
& t_{\text {test }}(4.665)>t_{\text {tabel }}(2,048)
\end{aligned}
$$


Jadi, berdasarkan taraf Signifikansi 5\%, $\mathrm{H}_{\mathrm{o}}$ yang berbunyi, "Tidak ada pengaruh metode pembelajaran tipe Jigsaw dan motivasi belajar terhadap kemampuan memahami paragraf" ditolak dan Ha yang berbunyi "Ada pengaruh metode pembelajaran tipe Jigsaw dan motivasi belajar terhadap kemampuan memahami paragraf” diterima.

\section{Pengkajian Tiga Hipotesis}

Dari hasil penelitian yang telah dipaparkan di atas, terbukti bahwa penerapan model pembelajaran Jigsaw dan motivasi belajar siswa berpengaruh kuat secara signifikansi terhadap peningkatan kemampuan memahami paragraf.

(1) Pengaruh metode pembelajaran Jigsaw terhadap hasil belajar

Hipotesis pertama berbunyi "ada pengaruh metode pembelajaran Jigsaw terhadap kemampuan memahami paragraf" diterima. Hal ini dibuktikan dengan hasil perhitungan Uji $\mathrm{t}\left(\mathrm{t}_{\text {test }}\right)$ yang menunjukkan angka signifikansi yaitu test $(4.366)>t_{\text {tabel }}(2,048)$.

Secara teoritis bahwa penerapan metode pembelajaran Jigsaw dalam proses pembelajaran berpengaruh kuat dan signifikan terhadap peningkatan kemampuan memahami paragraf siswa, sebab dapat meningkatkan dan mengembangkan kognitif dan kreativitas siswa. Oleh karena itu, dengan penerapan pembelajaran kooperatif jigsaw yang dilakukan oleh guru diharapkan pelajaran bahasa Indonesia tentang memahami paragraf akan diminati oleh siswa. Kerja sama inilah sedikit demi sedikit akhirnya akan menjadikan suatu kekompakan yang timbul dari isi hati peserta didik masing-masing.

(2) Pengaruh Motivasi belajar terhadap hasil Belajar

Hipotesis kedua berbunyi "ada pengaruh motivasi belajar terhadap kemampuan memahami paragraf" diterima. Hal ini dibuktikan dengan hasil perhitungan $\mathrm{Uji} \mathrm{t}\left(\mathrm{t}_{\text {test }}\right)$ yang menunjukkan angka signifikansi yaitu $t_{\text {test }}(2,088)>t_{\text {tabel }}(2,048)$.

Secara teoritis, motivasi belajar berpengaruh terhadap hasil belajar siswa. Hal ini telah dijelaskan bahwa siswa yang bermotivasi tinggi akan memiliki kemauan yang banyak dalam melakukan kegiatan pembelajaran serta memberikan arah yang tepat sesuai dengan kemampuannya guna mencapai hasil belajar. Siswa yang mempunyai motivasi belajar rendah pada umumnya tertinggal dan seringkali menjumpai kesulitan dalam belajarnya. Siswa yang memiliki motivasi belajar tinggi akan memperlihatkan aktivitas yang lebih tinggi dalam belajar.

(3) Pengaruh Metode Pembelajaran Jigsaw dan motivasi belajar terhadap Hasil belajar

Hipotesis ketiga yang menyatakan "ada pengaruh metode pembelajaran tipe Jigsaw dan motivasi belajar terhadap kemampuan memahami paragraf" diterima. Hal ini dibuktikan dengan hasil perhitungan rumus $\mathrm{Uji} \mathrm{t}\left(\mathrm{t}_{\text {test }}\right)$ yang menunjukkan angka signifikansi yaitu test $(4.665)>$ tabel $(2,048)$. Secara teoritis, penerapan metode jigsaw dan motivasi belajar secara bersama-sama berinteraksi dan berpengaruh kuat serta signifikansi dalam proses pembelajaran terhadap peningkatan hasil belajar siswa. Penerapan metode jigsaw menciptakan 
suasana yang menyenangkan dalam belajar, mendorong tumbuhnya gairah, merasa senang dan semangat dalam belajar, mendorong siswa untuk menyelesaikan tugasnya dalam bentuk memecahkan permasalahan secara berkelompok dengan tepat dan benar. Pada akhirnya, siswa memperoleh nilai yang tinggi dan membanggakan serta dapat bersaing dengan teman lainnya. Metode jigsaw juga mendorong keterlibatan siswa secara langsung dan aktif dalam proses pembelajaran, serta meningkatkan rasa percaya diri. Hal tersebut berujung pada peningkatan hasil belajar sisiwa.

SIMPULAN

Berdasarkan hasil dan pembahasan, dapat diketahui bahwa ada pengaruh metode pembelajaran Jigsaw terhadap kemampuan memahami paragraf, ada pengaruh motivasi belajar terhadap kemampuan memahami paragraf, dan ada pengaruh metode pembelajaran Jigsaw dan motivasi belajar terhadap kemampuan memahami paragraf. Dengan demikian, diharapkan guru dapat berkolaborasi dengan guru lain lebih kreatif dalam memanfaatkan media ataupun metode yang dikuasai sesederhana apapun itu untuk menarik minat siswa dalam pembelajaran, salah satunya adalah dengan menerapkan metode kooperatif Jigsaw.

\section{DAFTAR PUSTAKA}

Arikunto. 2002. Prosedur Penelitian. Jakarta: Penerbit P.T. Reneka Cipta.

Chotimah. 2004. Strategi Pembelajaran Kooperatif. Malang: Penerbit Surya Pena Gemilang.

Chotimah \& Dwitasari. 2009. StrategiStrategi Pembelajaran. Malang: Penerbit Surya Pena Gemilang.

Dimyati \& Mudjiono. 2002. Belajar dan Pembelajaran. Jakarta: Penerbit Reka Cipta.

Ibrahim. 2005. Pembelajaran Kooperatif. Surabaya: Penerbit Unesa-University Press.

Muhardjito. 2008.Pengaruh Teknik Pembelajaran Kooperatif Jigsaw. Jakarta: Prenada Media.

Purwanto. 2010. Metodologi Penelitian Kuantitatif.Yogyakarta: Pustaka Pelajar

Poerwadarminto. 2003. Kamus Umum Bahasa Indonesia. Bandung: Penerbit Transito
Sanjaya. 2006. Strategi Pembelajaran Kooperatif. Jakarta: Penerbit Prenada Media

Sardiman. 2002. Interaksi dan Motivasi Belajar Mengajar. Jakarta: Penerbit PT Raja Grafindo Persada

Siagian. 2004. Teori Motivasi dan Aplikasinya. Jakarta: Penerbit PT Andi Mahasatya

Setyosari. 2010. Metodologi Penelitian. Jakarta: Penerbit Kencana Media Group Sudjana. 2010. Penelitian Hasil Proses Belajar Mengajar. Bandung: Penerbit PT Remaja Rosdakarya Offset

Sujinah. 2015. Pedomam Penulisan Tesis dan Artikel Ilmiah. Surabaya: Muhammadiyah University Press 